\author{
ks. Krzysztof Mętlewicz \\ (D) https://orcid.org/0000-0002-8148-0119 \\ Uniwersytet Kardynała Stefana Wyszyńskiego w Warszawie
}

\title{
Solidarność jako skutek sakramentów inicjacji chrześcijańskiej
}

https://doi.org/10.15633/9788374389952.21

Pojęcie solidarności zdaje się być dzisiaj zdecydowanie bliższe odkryciom socjologii niż refleksji teologicznej. Wielki stownik języka polskiego ukazuje ją jako „postawę polegającą na zbieżności poglądów”, „gotowość do niesienia pomocy” oraz „wzajemne poleganie na sobie”. W istocie rzeczy solidarność jako społeczna zasada określa pewne ukierunkowane współdziałanie ludzi skupionych wokół jednej sprawy. Myliłby się jednak ten, kto uznałby to pojęcie za obce teologii katolickiej.

Podstawą życia Kościoła od zawsze są sakramenty². To przez nie prawdziwie działa miłujący Bóg, który obdarza swoje stworzenia uświęcającymi darami. Każdy obdarowany wraz z sakramentem otrzymuje także właściwe sobie zadania, z kolei święte znaki z założenia mają w nim skutkować konkretną duchową postawą. Najogólniej rzecz ujmując, sakramenty służą przemianie człowieka, który przez zjednoczenie $\mathrm{z}$ Bogiem otwiera się na swojego Dawcę, samego siebie i drugiego człowieka ${ }^{3}$. Jednym z realnych skutków sakramentu chrztu, bierzmowania czy Eucharystii jest dostrzeżenie $\mathrm{w}$ innych swoich braci, z którymi należy się solidaryzować w obliczu trudności i potrzeb.

Głównym celem artykułu będzie odpowiedź na pytanie: w jaki sposób sakramenty inicjacji chrześcijańskiej skutkują w wierzącym postawą solidarności? Chcąc udzielić pełnej i konkretnej odpowiedzi, opracowanie podzielone

\footnotetext{
1 Solidarność, w: Wielki stownik języka polskiego, red. B. Dunaj, Warszawa 2009, s. 648.

2 Zob. K. Mętlewicz, Sakramenty w historii i nauczaniu Kościoła katolickiego, „Ateneum Kapłańskie" 174 (2019) nr 2, s. 99-108.

3 Por. K. Mętlewicz, Sakramentalny wymiar życia chrześcijańskiego w teologii Josepha Ratzingera, „Teologia i Człowiek” 51 (2020) nr 3, s. 74. 63-80.
} 
zostanie na cztery punkty. Na wstępie należy omówić dokładnie sakramentalny wymiar trzech pierwszych sakramentów Kościoła w kontekście solidarności, by przez kolejne trzy punkty szczegółowo zaprezentować, w jaki sposób chrzest, bierzmowanie i Eucharystia otwierają przyjmującego sakrament na postawę miłości społecznej i braterskiego współdziałania. Końcowe wnioski pozwolą podsumować poszukiwania badawcze i wskazać, na ile udało się zrealizować postawiony we wstępie cel.

\section{Sakramentalny wymiar cnoty solidarności}

Katechizm Kościoła katolickiego naucza, że „solidarność jest cnotą wybitnie chrześcijańską" ". Już od początków Kościoła dawano świadectwo, że chrześcijan cechowała nadzwyczajna wrażliwość w sprawach wzajemnej pomocy i solidaryzowania się z ubogimi ${ }^{5}$. Oczywiście należy od razu zaznaczyć, że cnota ta nie ograniczała się jedynie do materialnych potrzeb. Warto w tym miejscu przywołać choćby te sytuacje, gdy apostołowie, określając siebie jako pozbawionych „srebra i złota”, uzdrawiają chorych i wskrzeszają umarłych ${ }^{6}$. Chrześcijańska solidarność nie skupiała się zatem na realizowaniu przyziemnych trosk, lecz szczególnie zabiegała o realizację potrzeb duszy. Stąd, jak naucza Magisterium, solidarność „urzeczywistnia podział dóbr duchowych jeszcze bardziej niż materialnych"7.

Nie jest przypadkiem, że rozwój tej właśnie cnoty miał związek ze sprawowanymi we wspólnocie Apostołów sakramentami. Św. Paweł w liście do Koryntian wskaże na problemy gromadzącej się na Eucharystii wspólnoty, która zamiast solidaryzować się z drugimi tworzy enklawy i własne zwyczaje $^{8}$. Warto jednak wspomnieć, że Pawłowa wrażliwość nie wynikała jedynie $\mathrm{z}$ Jego osobistego podejścia do wiary, lecz istotnego zadania Mistycznego Ciała Chrystusa, który realizując posługę diakonii, niesie pomoc ludziom. Stąd, jak przypomni Benedykt XVI, sakramenty, słowo Boże

4 Katechizm Kościoła katolickiego, Poznań 2002 (dalej: KKK), nr 1948, s. 459.

5 Dz 4, 34-35: „Nikt z nich nie cierpiał niedostatku, bo właściciele pól albo domów sprzedawali je i przynosili pieniądze [uzyskane] ze sprzedaży, i składali je u stóp Apostołów. Każdemu też rozdzielano według potrzeby".

$6 \mathrm{Dz} 3,6 ; 9,32-35 ; 9,36-43$.

7 KKK, nr 1948.

81 Kor 11, 21-22: „Każdy bowiem już wcześniej zabiera się do własnego jedzenia, i tak się zdarza, że jeden jest głodny, podczas gdy drugi nietrzeźwy. Czyż nie macie domów, aby tam jeść i pić? Czy chcecie znieważać Boże zgromadzenie i zawstydzać tych, którzy nic nie mają? Cóż wam powiem? Czy będę was chwalił? Nie, za to was nie chwalę!” 
i diakonia jednocześnie wyrażają wewnętrzna naturę Kościoła ${ }^{9}$. Sakramenty mają motywować do dzielenia się otrzymanym darem, zaś Słowo Boże ma wzywać do konkretnych ewangelicznych postaw. W rezultacie każda z trzech wskazanych przestrzeni życia Kościoła w pełni się przenika i konstytuuje. Dlatego można z pewnością mówić o ciągu przyczynowo-skutkowym między przyjętymi sakramentami inicjacji a rozwijaną w wierzących cnotą solidarności.

Trzy pierwsze sakramenty - chrzest, bierzmowanie i Eucharystia - jako stałe elementy „wtajemniczenia chrześcijańskiego, wprowadzają wierzącego w istotę chrześcijaństwa" ${ }^{10}$. Przyjęcie tych znaków ma jednoczyć z Chrystusem, ale również motywować do dawania czytelnego świadectwa wiary w świecie. Dlatego św. Jan Paweł II, nauczając o cnocie solidarności, powie, że można „dostrzec liczne punkty styczne pomiędzy nią a miłością, zna-

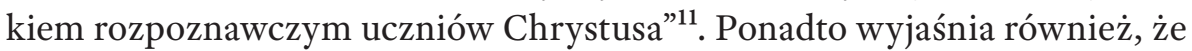
„W świetle wiary solidarność zmierza do przekroczenia samej siebie, do nabrania wymiarów specyficznie chrześcijańskich całkowitej bezinteresowności, przebaczenia i pojednania" ${ }^{\text {2 }}$. W ten sposób zarysowuje się teza, że sprawowane w Kościele sakramenty dają moc, by zapominać o sobie na rzecz bezinteresownej miłości agape. Można pójść jeszcze krok dalej i stwierdzić, że choć solidarność kojarzy się przede wszystkim z niesieniem szeroko rozumianego humanitarnego wsparcia najuboższym, to dla samego Kościoła taka działalność nie tylko nie stanowi niczego nowego, ale wyraża jego celowe i holistyczne funkcjonowanie.

\section{Chrzest sakramentem powszechnego braterstwa}

Nie sposób mówić o „ludzkim braterstwie” i „przyjaźni” ${ }^{33}$, jeśli wpierw nie uzna się wszystkich ludzi za dzieci jednego Ojca i swoiste „rodzeństwo” w Chrystusie. Taką perspektywę bez wątpienia otwiera pierwszy z sakramentów inicjacji - chrzest. Katechizm przypomni, że cnota solidarności ma dotyczyć wszystkich bytów stworzonych, gdyż „mają tego samego Stwórcę

9 Benedykt XVI, Encyklika Deus caritas est (dalej: DCE), Warszawa 20o6, nr 25, s. 33.

10 Sakramenty, w: Stownik teologiczny, red. A. Zuberier, t. 2, Katowice 1989, s. 221.

11 Jan Paweł II, Encyklika Sollicitudo rei socialis (dalej: SRS), w: Encykliki Ojca Świętego bt. Jana Pawta II, Kraków 2011, nr 40, s. 310.

12 SRS, nr 40, s. 310.

13 Katechizm stawia te wyrażenia jako synonimy solidarności: zob. KKK, nr 1939. 
i wszystkie są skierowane ku Jego chwale"14 . Przyjmujący chrzest nie ogranicza jednak swojego braterstwa jedynie ku innym ochrzczonym w myśl słów Ewangelii, że taka postawa nie jest dla wiary chrześcijańskiej niczym szczególnym ${ }^{15}$. Stąd wierzący ma pojmować braterstwo jako solidaryzowanie się z każdym człowiekiem stworzonym na obraz i podobieństwo Boga. Tak bowiem realizuje się prawdziwy skutek chrztu, czyli „narodzenie do nowego

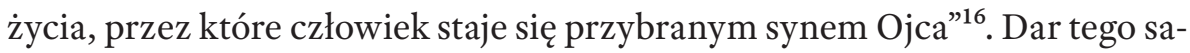
kramentu włącza do wspólnoty ludu Bożego ${ }^{17}$ i stanowi bramę dla pozostałych sześciu sakramentów ${ }^{18}$, lecz w żaden sposób nie motywuje do tworzenia enklawy rozumianej jako wzajemną pomoc tylko innym ochrzczonym.

Sobór Watykański II w konstytucji Gaudium et spes wyraża swoje braterskie stanowisko, przypominając, że „nie potrafi wymowniej okazać swojej solidarności, szacunku i miłości dla całej rodziny ludzkiej, w którą [Kościół] jest wszczepiony, jak nawiązując z nią dialog na temat owych różnych problemów, przynosząc światło czerpane z Ewangelii oraz dostarczając rodzajowi ludzkiemu zbawczych sił, jakie sam pod przewodnictwem Ducha Świętego otrzymuje od swego Założyciela" ${ }^{\text {"19 }}$. W podjętej w tym punkcie refleksji to zdanie jest ważne $z$ kilku powodów. Po pierwsze dlatego, że wiąże solidarność ze swoim sakramentalnym posłaniem. Ponadto wskazuje jasno, że wzajemne słuchanie ochrzczonych i nieochrzczonych oraz obecny między nimi miłosny dialog powinny być fundamentalną zasadą życia ludzi o różnych poglądach i wierzeniach. Magisterium wyraża tym samym pewność, że tak rozumiana współpraca pozwoli, by „przy pomocy łaski Bożej ukształtowali się prawdziwie nowi ludzie i budowniczowie nowej ludzkości”20.

Chrzest jako sakrament włączający w życie Kościoła potrzebuje właściwej przestrzeni do rozwoju i pomnażania otrzymanych łask. Naturalnym środowiskiem dla nowo ochrzczonych dzieci zawsze będą ich rodziny. Rodzice oraz chrzestni przyrzekają bowiem, że podejmą się wszelkich starań,

$4 \mathrm{KKK}, \mathrm{nr} 344$.

15 Mt 5, 46: „Jeśli bowiem miłujecie tych, którzy was miłują, cóż za nagrodę mieć będziecie?”

$16 \mathrm{KKK}, \mathrm{nr} 1279$.

$17 \mathrm{KKK}, \mathrm{nr} 1277$.

$18 \mathrm{KKK}, \mathrm{nr} 1280$.

19 Sobór Watykański II, Konstytucja o Kościele w świecie współczesnym Gaudium et spes (dalej: GS), w: Sobór Watykański II, Konstytucje. Dekrety. Deklaracje, Poznań 2002, nr 3, s. 527, 526-6o6.

20 GS, nr 30. 
aby dziecko zostało „wychowane w wierze oraz miłowało Boga i bliźniego”21. Ponadto, jak przypomni Katechizm, to właśnie „dom rodzinny stanowi naturalne środowisko wprowadzania dzieci w solidarność i odpowiedzialność wspólnotową" ${ }^{\text {22 }}$. Bycie w Kościele nie zakłada bierności Jego członków, lecz czynne zaangażowanie w rozwiązywanie problemów i uciszanie sporów. Dlatego właśnie „wspólnota z Chrystusem uwidacznia się w solidarności wierzących i wspólnym uczestniczeniu w cierpieniach i radościach wszystkich członków jednego Ciała Chrystusa" ${ }^{23}$. Stanie się tak tylko wówczas, gdy należący do Kościoła prócz jego instytucjonalnych przestrzeni dostrzegą również jego rodzinny i wspólnotowy wymiar. Niewykluczone, że warto znów na nowo odkryć rolę rodzin, które kształtują serca ochrzczonych dzieci, stanowiąc nie tylko „właściwe miejsce kształtowania cnót” ${ }^{24}$, lecz również „autentyczny początek i podporę żywej wiary"25.

Wobec powyższych odkryć można uczciwie stwierdzić, że sakrament chrztu skutkuje w pierwszej kolejności braterską solidarnością z całą rodziną ludzką. Wobec Stwórcy ludzkość stanowi Jego wybrane dzieło, które winno realnie dążyć do jedności i wzajemnego wsparcia. Solidarność chrzcielna stanowi również realny cel wychowania ochrzczonych, aby czuli się nie tylko zewnętrznie włączeni w lud Boży, lecz przede wszystkim zaangażowani w obecne w Nim radości i smutki.

\section{Bierzmowanie sakramentem odpowiedzialnego świadectwa}

Drugim omawianym w kolejności sakramentem inicjacji jest bierzmowanie. Katechizm wyraźnie zaznacza jego bezpośredni związek z omawianym wyżej sakramentem, gdyż „przyjęcie [bierzmowania] jest konieczne jako dopełnienie łaski chrztu"26. W podobnym tonie wypowiada się Sobór, przypominając, że ochrzczeni „przez sakrament bierzmowania jeszcze ściślej wiążą się z Kościołem, otrzymują szczególną moc Ducha Świętego i w ten sposób jeszcze mocniej zobowiązani są, jako prawdziwi świadkowie Chrystusowi do

\footnotetext{
21 Obrzędy chrztu dzieci dostosowane do zwyczajów diecezji polskich, Katowice 2014, s. 58.

$22 \mathrm{KKK}, \mathrm{nr} 2224$.

23 G. L. Müller, Dogmatyka katolicka, tłum. W. Szymona, Kraków 2015, s. 604.

$24 \mathrm{KKK}, \mathrm{nr} 2223$.

$25 \mathrm{KKK}, \mathrm{nr} 2225$.

$26 \mathrm{KKK}, \mathrm{nr} 1285$.
} 
szerzenia wiary słowem i uczynkiem oraz do bronienia jej”27. Wprost zaznacza się tutaj potrzeba kontynuowania i rozwijania tych owoców, jakie niesie z sobą sakrament chrztu. Nie sposób jednak nie zauważyć nowych zadań, jakie w kontekście przyjętego bierzmowania stoją przed wierzącym.

W szeroko szerokim ujęciu bierzmowanie ma motywować do szerzenia wiary. Jeśli w kontekście już odkrytych tez przyjmie się, że wybitnie chrześcijańska cnota - solidarność - jest ściśle związana z praktykowaną wiarą, to naturalną koniecznością będzie zwrócenie uwagi na związek owoców Ducha Świętego udzielanych w sakramencie z iście chrześcijańską odpowiedzialną postawą społeczną.

Warto zaznaczyć, że właściwe zrozumienie istoty bierzmowania ma olbrzymie znaczenie dla działań na rzecz dobra wspólnego. Dziś ów „społeczny charakter sakramentów zatarł się w świadomości ogółu katolików"28, a ich udział w świętych znakach staje się nierzadko czysto bierny i zewnętrzny. Aktualne zatem jest naglące wołanie Soboru Watykańskiego II, aby „chrześcijanie podczas misterium wiary nie byli obecni jak obcy i milczący widzowie, lecz aby przez obrzędy i modlitwy tę tajemnicę dobrze zrozumieli, w świętej czynności uczestniczyli świadomie, pobożnie i czynnie"29. Głębokie odkrycie znaczenia sakramentu i współpraca z łaską Bożą mogą i powinny iść w parze. W rezultacie bowiem przyniesie to stały rozwój wlanych w serce bierzmowanego owoców Bożego Ducha.

Mówiąc o solidarnym wymiarze skutków bierzmowania, na pierwszym miejscu należy wymienić pochodzący od Ducha dar pokoju. Jego istotna rola nie ogranicza się jedynie do powstrzymywania agresji czy zaniechania działań opresyjnych, lecz do konkretnego działania, tj. „czynnego zaangażowania w życie duchowe, rodzinne, społeczne, polityczne, naukowe, turystykę,

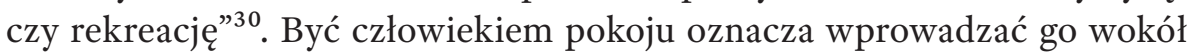
siebie, rozszerzając w ten sposób królestwo Boże ${ }^{31}$. Pokojowa postawa jest również publicznym przyznaniem się do Chrystusa, ponieważ On przyszedł nie po to, aby podnosić miecz ku wrogom, lecz aby przynieść pokój, którego nie zna świat. Stąd prawdziwym znakiem sprzeciwu wobec wojen, zawiści

27 Sobór Watykański II, Konstytucja dogmatyczna o Kościele Lumen gentium, w: Sobór Watykański II, Konstytucje. Dekrety. Deklaracje, Poznań 2002, nr 11, s. 113.

28 Sakramenty, dz. cyt., s. 223.

29 Sobór Watykański II, Konstytucja o liturgii świętej Sacrosanctum Concilium, nr 48, w: Sobór Watykański II, Konstytucje. Dekrety. Deklaracje, dz. cyt., s. 61.

30 A. Szczepanowski, Owoce Ducha Świętego w życiu chrześcijanina, Kraków 2010, s. 34.

31 Mt 5, 9: „Błogosławieni, którzy wprowadzają pokój, albowiem oni będą nazwani synami Bożymi”. 
i wzajemnych kłótni będzie postawa solidarnej jedności i harmonii. Praktykowanie tej cnoty w założeniu będzie polegać na „pełnieniu raczej cudzej woli niż swojej, pragnieniu, aby mieć raczej mniej niż więcej, szukaniu zawsze miejsca niższego i ustępowaniu drugim oraz pragnieniu i modlitwie, aby całkowicie wypełniła się w nas wola Boża" ${ }^{32}$.

Chrześcijańska odpowiedzialność społeczna ma swoje zakorzenienie również w cnocie solidarnego męstwa. Katechizm przypomni i tym razem, że bierzmowanie wzywa „do obrony wiary słowem i czynem, do mężnego wyznawania imienia Chrystusa oraz do tego, by nigdy nie wstydzić się Krzyża”33. W istocie katolickiej diakonii leży miłość i wyznawanie jej przez konkretne czyny. Stąd tylko mężny chrześcijanin może autentycznie ukazywać, że za jego odpowiedzialnym działaniem na rzecz wspólnoty Kościoła czy poza nią stoi żywa wiara w Chrystusa. Taki sposób interpretacji mężnego wyznawania wiary prezentuje Benedykt XVI, który w motu proprio De caritate ministranda naucza, iż organizacje katolickie winny „pełnić cenną funkcję pedagogiczną we wspólnocie chrześcijańskiej, wspomagając wychowywanie w duchu dzielenia się, szacunku i miłości, zgodnie z logiką Ewangelii Chrystusa" ${ }^{34}$. Człowiek wierzący nie solidaryzuje się z innymi dlatego, że uczy go tego świat, lecz przede wszystkim dlatego, że swoim przykładem nauczył go tego Chrystus. Stąd mężne wyznawanie wiary winno cechować się odpowiedzialnym odkrywaniem swojego miejsca w świecie jako ucznia Chrystusa. W innym wypadku solidarne zaangażowanie „rozmyje się w zwyczajnej organizacji opiekuńczej" ${ }^{35}$, podczas gdy solidarny chrześcijanin winien wszędzie wnosić czytelne świadectwo dzielenia się otrzymaną od Boga łaską.

Niezwykle ważnym owocem Ducha Świętego, służącym rozwojowi cnoty solidarności, jest chrześcijańska dobroć. Katolickie rozumienie dobra wskazuje na jego związek z moralnym działaniem ${ }^{36}$. Dobry człowiek czyni dobro moralne w sposób naturalny i bez żadnego przymusu ${ }^{37}$. W szeroko rozumia-

T. Kempis, O naśladowaniu Chrystusa, Warszawa 2007, III, 23.1, s. 136-137.

$\mathrm{KKK}, \mathrm{nr} 1303$.

Benedykt XVI, List motu proprio De caritate ministranda, Proemio, http://www.vatican.va/ content/benedic t-xvi/pl/motu_proprio/documents/hf_ben-xvi_motu-proprio_20121111_caritas. html (15.05.2021).

Benedykt XVI, List motu proprio De caritate ministranda, dz. cyt.

Zob. B. Inlender, Dobro, w: Encyklopedia katolicka, t. 3, red. R. Łukaszyk, L. Bieńkowski, F. Gryglewicz, Lublin 1985, kol. 1375-1377.

J. Hanslmeier, Gut, w: Lexikon für Theologie und Kirche, Hrsg. J. Hanslmeier, Freiburg 1960, kol. 1284 . 
nej etyce stanowi „realizację istoty człowieczeństwa”38. Przez swój zakres treściowy bardzo często wiąże się z cnotą życzliwości, która zakłada wzajemne działanie na korzyść. Pewne jest jedno, że ten konkretny owoc sakramentu bierzmowania w naturalny sposób buduje międzyludzką solidarność. Jest tak dlatego, ponieważ „człowiek zachęcony przykładem dobroci odmienia swoje życie na lepsze i rodzi się do dobroci wobec innych"39. Bezpośrednie otwarcie się na drugiego wznosi się ponad to, co dzieli, skupiając się na wspólnym ludzkim szukaniu dobra wspólnego. Jak przypomni Encyklopedia katolicka, „myśl chrześcijańska wiąże solidarność z bezinteresowną miłością bliźniego oraz stałą gotowością do pojednania" ${ }^{40}$. Bierzmowany ma więc zadanie rozwijać dar dobroci nie tylko jako sposób działania, lecz przede wszystkim jako ciągłe odkrywanie i realizację wzajemnego dobra z każdym człowiekiem.

\section{Eucharystia sakramentem bezinteresownego dzielenia}

Z pewnością najważniejszym sakramentem wśród znaków inicjacji, ale także wszystkich misteriów Kościoła jest Eucharystia. Przewyższa ona wszystko co zostało dane ludowi Bożemu, stanowiąc „szczyt, do którego zmierza działalność Kościoła, i jednocześnie źródło, z którego wypływa cała jego moc”41. Wszystkie sakramenty - również wszelka działalność publiczna wspólnoty wierzących - „wiążą się ze świętą Eucharystią i do niej zmierzają" ${ }^{42}$, ponieważ w niej zawarte jest „całe duchowe dobro Kościoła” ${ }^{43}$. Ponadto, w kontekście podjętego celu badawczego warto również zaznaczyć, ̇̇e „Najświętsza Eucharystia dopełnia wtajemniczenie chrześcijańskie" ${ }^{44}$, ponieważ w przedziwny sposób „podtrzymuje, pogłębia i odnawia życie łaski otrzymane na chrzcie”45.

Tak przedstawiony sposób pojmowania Eucharystii pozwala zrozumieć, jak bardzo jej przeżywanie motywuje wierzących do szeroko rozumianej solidarności. Każdy przystępujący do ołtarza winien przejawiać świadomość,

38 J. Hanslmeier, Gut, dz. cyt., kol. 1285.

39 A. Szczepanowski, Owoce Ducha, dz. cyt., s. 52.

40 J. Filipkowski, Solidaryzm, w: Encyklopedia katolicka, t. 18, red. E. Gigilewicz, Lublin 2013, kol. 578.

41 Sobór Watykański II, Konstytucja o liturgii, dz. cyt., nr 10.

42 Sobór Watykański II, Dekret o posłudze i życiu prezbiterów Presbyterorum ordinis, w: Sobór Watykański II, Kontytucje. Dekrety. Deklaracje, dz. cyt., nr 5, s. 484.

43 Sobór Watykański II, Presbyterorum ordinis, $\mathrm{nr} 5$, s. 484.

$44 \mathrm{KKK}, \mathrm{nr} 1322$.

$45 \mathrm{KKK}, \mathrm{nr} 1392$. 
że uczestniczy w tajemniczym obdarowaniu, na które nie zasługuje ani przez osobistą sprawiedliwość, ani tym bardziej przez szczególne duchowe zasługi. Jak powie Benedykt XVI, Eucharystia jest darem „absolutnie bezinteresownym” ${ }^{46} \mathrm{i}$ w swej istocie przez nią „,całe Boże życie dociera do nas” ${ }^{\text {"7 }}$. Obecność Chrystusa w tym właśnie sakramencie jest szczególna, „substancjalna i przez nią uobecnia się cały Chrystus, Bóg i człowiek"48. On sam pragnął pozostać wśród ludzi „w tajemniczy sposób jako Ten, który nas umiłował i wydał za nas samego siebie" ${ }^{49}$. Tym samym może i chce motywować każdego przyjmującego sakrament do miłości na swój wzór: pełnego poświęcenia oddania i dzielenia się wszystkim ze wszystkimi.

Kult należny Bogu w Eucharystii z natury rzeczy jest zobowiązującym przywilejem wierzących. Wierząc, że wszystko pochodzi od Stwórcy, a każda łaska jest nieoczekiwanym darem, rodząca się w sercu wdzięczność jest niejako kontynuacją obdarowania. Trzeba jednak jasno zaznaczyć, że Eucharystia - jak każdy sakrament - niesie ze sobą konkretne implikacje moralne. Przybliża je m.in. Joseph Ratzinger, gdy wskazuje na istotę duchowej więzi wierzącego z Chrystusem. Zjednoczenie z Panem, będące jednoczesną Komunią z bliźnim, „staje się życiem, ciałem i krwią w codzienności bycia z drugim i obok drugiego" 50 . Ponadto "gdy Eucharystia jest rozumiana w całej głębi zjednoczenia każdej jednostki z Panem, wtedy właśnie staje się w najwyższym stopniu sakramentem społecznym" ${ }^{51}$. Jan Paweł II pójdzie jeszcze krok dalej, uświadamiając, iż wierzący przez przyjęcie Najświętszego Sakramentu nie powinien przyjmować go z myślą tylko o sobie samym, zaś msza święta ze swej natury powinna być sprawowana „w kontekście spójności także zewnętrznych więzów komunii" "52.

Eucharystia jest wielką szkołą społecznej solidarności. To ona uczy „być zobowiązanym wobec drugiego - zdrowi wobec chorych, bogaci wobec ubogich [...] - ze świadomością wzajemnej za siebie odpowiedzialności”53. Cały czas również uświadamia, „że gdy dajemy - otrzymujemy, i że możemy

46 Benedykt XVI, Posynodalna adhortacja apostolska Sacramentum caritatis, Warszawa 2007 (dalej: $\mathrm{SC})$, nr 8, s. 12.

$47 \mathrm{SC}, \mathrm{nr} 8$.

$48 \mathrm{KKK}, \mathrm{nr} 1374$.

$49 \mathrm{KKK}, \mathrm{nr} 1380$.

50 J. Ratzinger, Eucharystia, komunia i solidarność, w: J. Ratzinger, Teologia liturgii, red. G. L. Müller, pol. red. K. Góźdź, M. Górecka, tłum. W. Szymona, Lublin 2012, s. 408 (Opera Omnia, 11).

51 J. Ratzinger, Eucharystia, komunia i solidarność, dz. cyt., s. 408.

52 Jan Paweł II, Encyklika Ecclesia de Eucharistia (dalej: EE), w: Encykliki, dz. cyt., nr 38, s. 8oo.

53 J. Ratzinger, Eucharystia, komunia i solidarność, dz. cyt., s. 411. 
zawsze dawać tylko to, co również my sami otrzymaliśmy, co zatem nigdy nie jest naszą wyłączną własnością" ${ }^{54}$. Ciągłe uświadamianie sobie eucharystycznego obdarowania tworzy wewnętrzny imperatyw, by łaski Chrystusa, tj. pokój, przebaczenie i dobroć - przełożyły się na współpracę we wspólnocie Kościoła i na całym świecie. Stąd za Benedyktem XVI można powiedzieć, że Eucharystia „przynagla tych, którzy są w konflikcie, by przyspieszyli pojednanie, otwierając się na dialog oraz budowanie sprawiedliwości. Nie ma wątpliwości, że warunkiem budowania prawdziwego pokoju jest przywrócenie sprawiedliwości, pojednania i przebaczenia" ${ }^{\text {55 }}$. Stanowi to szczególnie dziś niegasnące wezwanie dla chrześcijaństwa, które „Zawsze zmierzało do zjednoczenia ludzkości” ${ }^{56}$ i „przezwyciężenia panoszącej się kultury egoizmu, nienawiści, zemsty i wrogości" 57 .

Społeczny, a przez to i solidarny wymiar przeżywanego misterium Eucharystii, prezentuje szczegółowo adhortacja Sacramentum caritatis. Papież z wielką mocą przypomina, że każdy „kto uczestniczy w Eucharystii, powinien angażować się w budowanie pokoju w naszym świecie, naznaczonym przemocą i licznymi wojnami, a dziś w szczególny sposób przez terroryzm, korupcję ekonomiczną oraz wykorzystywanie seksualne" ${ }^{58}$. Od razu da się zauważyć swoiście zadaniowy wymiar przeżywanej mszy świętej. Solidarność, kształtowana jako cnota z gruntu chrześcijańska, ma się realizować jako odpowiedź miłości na zło świata. Nie ma jednak polegać na słownym deklarowaniu niezgody na zło i niesprawiedliwość, ale aktywnej pracy na rzecz zwalczania wszelkich wad i patologii społecznych.

Chrystus przez Eucharystię w szczególny sposób „nakłania nas i uwrażliwia na sytuacje nędzy, w których znajduje się wciąż większa część ludzkości”59. Nie można zatem pozostawać biernym i milcząco zgadzać się na taki stan rzeczy. Uczestnicząc w Eucharystii, wierzący nie tylko ma oddawać cześć Bogu przez gesty i słowa, lecz szczególnie wyrażać ma się to przez czyny i miłość. To właśnie ten sakrament „daje nam też nową siłę i odwagę, by pracować wytrwale nad budowaniem cywilizacji miłości” ${ }^{60}$, bo właśnie

54 J. Ratzinger, Eucharystia, komunia i solidarność, dz. cyt, s. 411.

55 SC, nr 89.

56 J. Ratzinger, Eucharystia, komunia, solidarność, dz. cyt., s. 412.

57 Jan Paweł II, Posynodalna adhortacja apostolska Christifideles laici, nr 42, https://opoka.org.pl/ biblioteka/W/WP/jan_pawel_ii/adhortacje/christifideles.html (15.05.2021).

58 SC, nr 89.

$59 \mathrm{SC}, \mathrm{nr} 90$.

$60 \mathrm{SC}, \mathrm{nr} 90$. 
przez takie realne działanie chrześcijanie „czerpiąc natchnienie z Eucharystii, która jest sakramentem miłości, stają się konkretnym jej przejawem" ${ }^{61}$. Jan Paweł II przypomni ponadto, że motywowane sakramentem „zaangażowanie na rzecz przemiany świata zgodnie $\mathrm{z}$ Ewangelią, wyraża aspekt eschatologiczny Ofiary eucharystycznej i całego życia chrześcijańskiego"62. Eucharystyczna solidarność jest więc pełnym wrażliwości działaniem na rzecz zwalczania wszelkiej ludzkiej nędzy, stanowiąc posłanie misyjne w świecie.

Wspomniana już adhortacja o Eucharystii nie ogranicza się jedynie do postawienia ogólnych wezwań wobec wierzących. Benedykt XVI konkretyzuje apostolską działalność przyjmujących Eucharystię przede wszystkim do tego, „byśmy czynili wszystko co możliwe, współdziałając z instytucjami międzynarodowymi, państwowymi i prywatnymi, by zlikwidować lub przynajmniej zmniejszyć w świecie zgorszenie głodu oraz niedożywienia, z powodu którego cierpi tak wiele milionów ludzi, nade wszystko w krajach będących na drodze rozwoju"63.

Wyraźnie koresponduje to z innym dokumentem papieża, gdy definiując chrześcijański program działania, sprowadza go do stwierdzenia „serce, które widzi” ${ }^{64}$. Karmione Eucharystią serce „widzi, gdzie potrzeba miłości i działa konsekwentnie" ${ }^{65}$. Ponadto ma szukać „inicjatyw wspólnotowych [...] ma przewidywać, programować i współpracować” ${ }^{66}$, stąd można śmiało przyznać, że solidarność nie oznacza tutaj jedynie pochylania się ze wsparciem nad potrzebującymi, lecz szukania wspólnotowej współpracy z każdym, kto chce taką podjąć. Tak realizuje się prawdziwie społeczny wymiar Mszy świętej, ponieważ „każde kościelne wydarzenie ma charakter znaku, poprzez który Bóg się nam udziela i nas przynagla" ${ }^{67}$. W tym też duchu Magisterium wzywa, ażeby „chrześcijanie czuli się bardziej niż kiedykolwiek wezwani, aby nie zaniedbywać obowiązków przynależnych mieszkańcom tej ziemi” ${ }^{68}$.

Niezwykle ciekawą przestrzenią solidarności eucharystycznej jest praca na rzecz ochrony stworzenia. Papież Benedykt XVI wskazuje, iż „słuszne zatroskanie o warunki ekologiczne [...] zobowiązuje do odpowiedzialnego

\footnotetext{
61 SC, nr 90.

62 EE, nr 21.

63 SC, nr 91.

64 DCE, nr 31.

65 DCE, nr 31.

66 DCE, nr 31.

$67 \mathrm{SC}, \mathrm{nr} 92$.

68 GS, nr 39.
} 
działania na rzecz ochrony stworzenia" ${ }^{69}$. Postawa ta wynika z wewnętrznego przekonania, że ziemia, na której wszyscy żyją, „nie jest niezależną rzeczywistością, samą materią", ale miejscem, gdzie bracia i siostry w Chrystusie wspólnie dzielą się jej hojnymi surowcami. Jak zauważył ks. Jarosław Babiński, „panowanie człowieka nie może charakteryzować się brakiem odpowiedzialności, bezmyślnością, egoizmem, zachłannością czy niesprawiedliwością. Musi być pozytywnym zatroskaniem o porządek stworzenia, wkładem w jego rozwój, w równowagę całego wszechświata"70. Człowiek wdzięczny Bogu za dany mu świat, przynosi do ołtarza to, co wcześniej otrzymał. Analogicznie zatem, odkrywając chwałę Bożą obecną w Eucharystii pod postaciami chleba i wina, winien również odkrywać tę obecność w poddanym mu świecie stworzonym. Dzieląc się łaskami Eucharystii, chrześcijanin czuje również wewnętrzny imperatyw, by uczestniczyć w sprawiedliwej dystrybucji wszystkich rzeczy ziemskich. Tak też realizuje się cnota solidarności, rozumiana jako „mocna i trwała wola angażowania się na rzecz dobra wspólnego, czyli dobra wszystkich i odpowiedzialności za wszystkich"71. Skoro więc wszystko co na świecie należy do całej rodziny ludzkiej, stąd w duchu apostolskiego posłania eucharystycznego należy nie tylko to wyraźnie podkreślać, lecz przede wszystkim zadbać o właściwy porządek dystrybucji dóbr oraz szeroko rozumianą równowagę i sprawiedliwość społeczną.

$$
* * *
$$

Sakramenty inicjacji chrześcijańskiej stanowią dla wierzących trzy niezwykle istotne przestrzenie duchowego i społecznego rozwoju. Zwróciwszy uwagę na wywodzące się z ich przyjęcia skutki można przyjąć, że w swej istocie tak chrzest, bierzmowanie, jak i Eucharystia motywują do działań stricte solidarnych, a co za tym idzie - realizują swój społeczny wymiar. Postawiony we wstępie cel badawczy pozwolił odkryć, że każdy z sakramentów inicjacji odkrywa w wierzącym wewnętrzny imperatyw do działań na rzecz definiowanej przez Magisterium przyjaźni społecznej. Chrzest wzywa do postawy pełnej braterstwa, która przezwycięża podziały, usuwa enklawy i zaprasza

69 SC, nr 92.

70 J. Babiński, Stworzoność człowieka jako fundament ekologicznej odpowiedzialności, „Forum Teologiczne” 21 (2020), s. 135.

71 SRS, nr 38. 
wszystkich do dialogu. Bierzmowanie wspiera w odpowiedzialnym szukaniu własnego miejsca w świecie oraz budowaniu ładu społecznego przez pokój i dobroć. Z kolei Eucharystia jako najwyższy dar miłości Boga w naturalny sposób motywuje do wrażliwości na dysproporcje materialne i duchowe, aby żaden człowiek nie pozostał bez solidarnego wsparcia, a odpowiedzią na zło i podziały były sprawiedliwość i jedność. Teraz dopiero można stanowczo zaznaczyć, że sakramenty inicjacji chrześcijańskiej nie tylko pomagają w budowaniu solidarności społecznej, lecz z zasady do tego dążą, czyniąc tytułowa cnotę współczesnym hasłem przewodnim swoich działań w świecie.

\section{Bibliografia}

Babiński J., Stworzoność cztowieka jako fundament ekologicznej odpowiedzialności, „Forum Teologiczne" 21 (2020), s. 125-138.

Benedykt XVI, Encyklika Deus caritas est, Warszawa 2006.

Benedykt XVI, List motu proprio De caritate ministranda, http://www.vatican. $\mathrm{va} /$ content/b enedict-xvi/pl/motu_proprio/documents/hf_ben-xvi_motuproprio_20121111_caritas. html (15.05.2021).

Benedykt XVI, Posynodalna adhortacja apostolska Sacramentum caritatis, Warszawa 2007.

Filipkowski J., Solidaryzm, w: Encyklopedia katolicka, t. 18, red. E. Gigilewicz, Lublin 2013, kol. 578-582.

Hanslmeier J., Gut, w: Lexikon für Theologie und Kirche, Hrsg. J. Hanslmeier, Freiburg 1960, kol. 1284-1288.

Inlender B., Dobro, w: Encyklopedia katolicka, t. 3, red. R. Łukaszyk, L. Bieńkowski, F. Gryglewicz, Lublin 1985, kol. 1375-1378.

Jan Paweł II, Encyklika Ecclesia de Eucharistia, w: Encykliki Ojca Świętego bt.Jana Pawta II, Kraków 2011, s. 777-814.

Jan Paweł II, Encyklika Sollicitudo rei socialis, w: Encykliki Ojca Świętego bł. Jana Pawta II, Kraków 2011, s. 275-321.

Jan Paweł II, Posynodalna adhortacja apostolska Christifideles laici, https://opoka.org. pl/biblioteka/W/WP/jan_pawel_ii/adhortacje/christifideles.html (15.05.2021).

Katechizm Kościoła katolickiego, Poznań 2002.

Kempis T., O naśladowaniu Chrystusa, Warszawa 2007.

Mętlewicz K., Sakramentalny wymiar życia chrześcijańskiego w teologii Josepha Ratzingera, „Teologia i Człowiek” 51 (2020) nr 3, s. 63-80. 
Mętlewicz K., Sakramenty $w$ historii i nauczaniu Kościoła katolickiego, „Ateneum Kapłańskie" 174 (2019) nr 2, s. 99-108.

Müller G. L., Dogmatyka katolicka, tłum. W. Szymona, Kraków 2015.

Obrzędy chrztu dzieci dostosowane do zwyczajów diecezji polskich, Katowice 2014.

Ratzinger J., Eucharystia, komunia i solidarność, w: J. Ratzinger, Teologia liturgii, red. G.

L. Müller, pol. red. K. Góźdź, M. Górecka, tłum. W. Szymona, Lublin 2012, s. 40o415 (Opera Omnia, 11).

Stownik teologiczny, red. A. Zuberier, t. 2, Katowice 1989.

Sobór Watykański II, Dekret o posłudze i życiu prezbiterów Presbyterorum ordinis, w:

Sobór Watykański II, Konstytucje. Dekrety. Deklaracje, Poznań 2002, s. 478-508.

Sobór Watykański II, Konstytucja dogmatyczna o Kościele Lumen gentium, w: Sobór

Watykański II, Konstytucje. Dekrety. Deklaracje, Poznań 2002, s. 104-163.

Sobór Watykański II, Konstytucja o Kościele w świecie współczesnym Gaudium et spes,

w: Sobór Watykański II, Konstytucje. Dekrety. Deklaracje, Poznań 2002, s. 526-6o6. Sobór Watykański II, Konstytucja o liturgii świętej Sacrosanctum Concilium, w: Sobór

Watykański II, Konstytucje. Dekrety. Deklaracje, Poznań 2002, s. 49-78.

Szczepanowski A., Owoce Ducha Świętego w życiu chrześcijanina, Kraków 2010.

Wielki stownikjezyka polskiego, red. B. Dunaj, Warszawa 2009.

\section{Abstrakt}

\section{Solidarnośćjako skutek sakramentóre inicjacji chrześcijańskiej}

Artykuł przybliża temat solidarności jako skutku sakramentów inicjacji chrześcijańskiej. Autor najpierw definiuje zarówno kościelne rozumienie cnoty solidarności, jak i sakramentów inicjacji chrześcijańskiej. Przez trzy kolejne punkty szczegółowo omawia skutki poszczególnych sakramentów pod kątem wynikających z nich implikacji moralnych do budowania świata w duchu sprawiedliwości społecznej. W podjętej analizie bazuje zarówno na nauczaniu Soboru Watykańskiego II, wypowiedziach papieży, jak i na refleksji teologicznej, która jest współczesną próbą sprecyzowania zadań, przed jakimi stoi Kościół katolicki. Wreszcie w podsumowaniu autor wskazuje, na jakie konkretnie cechy solidarności ukierunkowują wierzącego święte znaki sakramentalne.

\section{Słowa kluczowe}

sakramenty inicjacji, chrzest, bierzmowanie, Eucharystia, solidarność 